\title{
Protective effects of Buchholzia coriacea seeds extract and fractions on blood glucose and hyperlipidemia in diabetic rats
}

\author{
Theophine Chinwuba Akunne*, Laura C. Ilogu, Bonaventure C. Obi, Peter A. Akah
}

Department of Pharmacology and Toxicology, University of Nigeria, Nsukka, Nigeria

Received: 22 May 2017

Revised: 30 May 2017

Accepted: 24 June 2017

*Correspondence to:

Dr. Theophine Chinwuba

Akunne,

Email: theokuba@yahoo.com

Copyright: (C) the author(s), publisher and licensee Medip Academy. This is an openaccess article distributed under the terms of the Creative Commons Attribution NonCommercial License, which permits unrestricted noncommercial use, distribution, and reproduction in any medium, provided the original work is properly cited.

\begin{abstract}
Background: The Buchholzia coriacea seeds (Capparaceae) are used in Nigerian ethnomedicine for treatment of hyperglycemia. Our aim, therefore, is to evaluate antihyperglycemic and hypolipidemic effects of extract and fractions of Bulcholzia coriacea seeds.

Methods: The cut, dried and pulverized seeds were extracted with a mixture of methanol-dichloromethane $(1: 1)$ which yielded the crude extract, MDE. The MDE was fractionated using bioactive guided procedure and yielded hexane fraction (HF), ethylacetate fraction (EF) and methanol fraction (MF). Alloxaninduced diabetes, normoglycemic test and oral glucose tolerance test (OGTT) were the antidiabetic models employed, while hypolipidemic study was performed using standard assay kits to determine the serum total cholesterol (TC) triglycerides (TG) and low density lipoproteins (LDL). Acute toxicity test of the extract was performed using Lorke's method while qualitative and quantitative phytochemical analyses were also performed using standard procedures.

Results: The results showed an oral median lethality dose (LD50) greater than $5000 \mathrm{mg} / \mathrm{kg}$. The extract and fractions showed significant antihyperglycemic effect comparable and in synergy to metformin, a standard agent. The extract $(200 \mathrm{mg} / \mathrm{kg})$ showed the highest percentage blood glucose reduction (PBGR) of $52.89 \%$ while ethylacetate fraction $(\mathrm{EF}, 400 \mathrm{mg} / \mathrm{kg}$ ) showed PBGR of $50.84 \%$. Also, the MDE and hexane fraction (HF) showed a significant reduction of TC, TG and LDL and related increase in HDL-C levels in diabetic treated rats.

Conclusions: The extract and the fractions of Buchholzia coriacea seeds possess antihyperglycemic and antihyperlipidemic effects and showed same mechanism of action as metformin, thus providing scientific rationale for its folkloric use.
\end{abstract}

Keywords: Antihyperglycemia, Buchholzia coriacea, Diabetic rats and quantitative phytochemicals, Hypolipidemia

\section{INTRODUCTION}

Diabetes mellitus (DM) is a multifaceted global health burden involving multiple pathological defects, including impaired islet function and insulin resistance, which result in impaired glucose tolerance and abnormal high fasting hepatic glucose production. ${ }^{1}$ This multi factorial disease has been ranked seventh among the leading causes of death and is considered third when its fatal complications are taken into account. ${ }^{2}$ Recent studies have shown that an estimate of 381.8 million adults were with diabetes in 2013 and this number according to the International Diabetes Federation (IDF) report, is likely to increase up to 591.9 million adults or more by the year $2035 .^{3}$ However, in Africa alone it has been projected that the number of individuals with DM may increase to 41.5 million in $2035 .{ }^{4}$ Long term diabetes is associated with several comorbidities, such as erectile dysfunction, retinopathy, poor wound healing, kidney failure and heart disease due to micro- and macro- vascular complications. ${ }^{5}$ Despite considerable progress in the treatment of diabetes by oral antidiabetic drugs, search for newer drugs continues because of several limitations of existing synthetic agents. ${ }^{6}$ Since time immemorial, plant extracts have been used to treat patients with diabetes in various parts of the world under complementary and alternative medicine. Medicinal plants provide useful source of oral hypoglycaemic 
compounds for the development of new pharmaceutical leads as well as a dietary supplement to existing therapies. The ethno botanical information reports showed that about 800 plants may possess antidiabetic properties. ${ }^{7,8}$ Published research has shown that Buchholzia coriacea seeds extract exhibited anthelmintic, antidiabetic, antimicrobial and cytotoxicity effects. ${ }^{9-13}$ Therefore, this study was designed and aimed to evaluate the antihyperglycemic and hypolipidemic effects of extract and fractions of Buchholzia coriacea seeds.

\section{METHODS}

\section{Collection and preparation of plant material}

Mature fruits of Buchholzia coriacea were collected in the month of August, from Nsukka in Enugu State, Nigeria and authenticated by Mr. A. Ozioko a taxonomist with the International Centre for Ethnomedicine and Drug Development (InterCEDD), Nsukka, Enugu State, Nigeria. The seeds were removed from the seed pulp, sliced and dried under shade. The dried seeds were pulverized and extracted with a 1:1 mixture of methanol and dichloromethane by continuous extraction in a Soxhlet apparatus and concentrated under reduced pressure at a temperature of $40^{\circ} \mathrm{C}$ to obtain methanol-dichloromethane extract (MDE). The MDE obtained was stored in an airtight container in a refrigerator for screening studies.

\section{Solvent guided fractionation}

About $250 \mathrm{~g}$ of MDE was separated using chromatographic apparatus with silica gel (60-120 mesh size), and successively eluted with n-hexane, ethylacetate and methanol in increasing order of polarity. The solvent fractions obtained were concentrated to obtain hexane (HF; 48.0g), ethylacetate (EF; 62g) and methanol (MF; $79.8 \mathrm{~g}$ ) fractions which were subjected to bioactivity guided studies.

\section{Experimental animals}

Adult Sprague-dawley rats (200-280g) and mice (20-25g) were obtained from the animal house facility of the Department of Pharmacology and Toxicology; Faculty of Pharmaceutical Sciences, University of Nigeria, Nsukka. They were kept in standard laboratory conditions and fed with rodent pellets (Guinea Feeds Nigeria Limited) and water ad libitum. All animal experiments were conducted in compliance with the National Institute of Health Guidelines for Care and Use of Laboratory Animals (Pub. No. $85-23$, revised 1985) and approval of the University Ethical Committee on the use of laboratory animals.

\section{Phytochemical analyses}

Qualitative and quantitative phytochemical analyses of the MDE were performed to identify type and the quantity per $100 \mathrm{~g}$, of plant secondary metabolites present in the extract. Qualitative phytochemical analysis was performed using standard procedures outlined by Harborne and Trease and Evans. ${ }^{14,15}$ Briefly, frothing test for saponins, Salkowski test for terpenoids, Liebermann-Burchard tests for steroids, ferric chloride tests for tannins, Keller-Killiani test for glycosides, Dragendoff's and Mayer's test for alkaloids, Fehling's test for proteins, iodine tests for carbohydrates and ammonia test for detection of flavonoids. Also quantitative phytochemical analysis was carried out on the MDE and fractions of Buchholzia coriacea seeds. The standard procedures outlined by Obadoni and Ochuko, were used for the quantitative determination of tannins, alkaloids, saponins and flavonoids respectively. ${ }^{16}$

\section{Acute toxicity studies ( $\left.\mathrm{LD}_{50}\right)$}

The acute toxicity of the MDE was determined by the method of Lorke. ${ }^{17}$ Briefly, in the first phase, 9 mice were divided into 3 groups of 3 mice each and were treated with extract doses of 10,100 , and $1000 \mathrm{mg} / \mathrm{kg}$ body weight per oral. The animals were observed for 24 hours for signs of toxicity. In the second phase, 4 mice were used. Three of the mice were treated with extract doses of 1600, 2800 and $5000 \mathrm{mg} / \mathrm{kg}$ body weight, while the fourth mouse served as control. The animals were observed for another 24 hour.

\section{Normoglycemic test}

Normoglycemic rats fasted for $16 \mathrm{~h}$ were randomly divided into eight groups (1-8) of five animals per group. Groups 1 and 2 received 100 and $5 \mathrm{mg} / \mathrm{kg}$ body weight of the standard drugs metformin (MET) and glibenclamide (GLI) respectively. Groups 3, 4 and 5 received 100, 200 and $400 \mathrm{mg} / \mathrm{kg}$ of MDE respectively. Groups 6 and 7 received co-administered doses of $100 \mathrm{mg} / \mathrm{kg}$ MET + $100 \mathrm{mg} / \mathrm{kg} \mathrm{MDE}$, and $5 \mathrm{mg} / \mathrm{kg}$ GLI $+100 \mathrm{mg} / \mathrm{kg} \mathrm{MDE}$ respectively. Group 8, control, received $0.4 \mathrm{ml}$ of $10 \%$ Tween 80 solution. These treatments were done once as a single dose and blood glucose levels were monitored prior $(0 \mathrm{~h})$ and at 2, 4, 6, $8 \mathrm{~h}$ after administration. Afterwards the percentage blood glucose reduction (PBGR) was calculated for the MDE and standard agents.

\section{Oral glucose tolerance test (OGTT)}

Adult rats fasted for $16 \mathrm{hrs}$ were randomly divided in groups (1-17) of five animals per group. Groups 1 and 2 (the positive controls) were treated with 100 and $5 \mathrm{mg} / \mathrm{kg}$ body weight of metformin (MET) and glibenclamide (GLI) respectively. Groups 3, 4 and 5 received 100, 200, $400 \mathrm{mg} / \mathrm{kg}$ body weight of MDE. Groups 6 and 7 received co-administered doses of $100 \mathrm{mg} / \mathrm{kg}$ MET $+100 \mathrm{mg} / \mathrm{kg}$ $\mathrm{MDE}$, and $5 \mathrm{mg} / \mathrm{kg} \mathrm{GLI}+100 \mathrm{mg} / \mathrm{kg} \mathrm{MDE}$ respectively. Groups 8, 9 and 10 received 100, 200 and $400 \mathrm{mg} / \mathrm{kg}$ of Hexane fraction (HF) respectively. Groups 11, 12 and 13 received 100, 200 and $400 \mathrm{mg} / \mathrm{kg}$ body weight of Ethylacetate fraction (EF). Groups 14, 15 and 16 received 100,200 and 400mg/kg body weight of Methanol fraction (MF). Group 17, the diabetic control received $0.4 \mathrm{ml}$ of $10 \%$ Tween 80 solution. One hour after administration, the 
animals were fed with high glucose load $(2 \mathrm{~g} / \mathrm{kg})$. Blood glucose levels were monitored prior $(0 \mathrm{~h})$ and at 30, 60, 90, 180 minutes after glucose administration and percentage blood glucose reduction (PBGR) calculated.

\section{Induction of experimental diabetes in rats}

The rats were fasted for $12 \mathrm{~h}$ with free access to water. After fasting period, the basal fasting blood glucose levels (BGL) were measured using Acu-Check Kit (Roche, Germany). Further, diabetes was then induced by single intraperitoneal (IP) injection of alloxan monohydrate $(120 \mathrm{mg} / \mathrm{kg})$.

The rats were given $5 \%$ dextrose solution to overcome the fatal hypoglycaemia that may result from the massive pancreatic insulin release due to the administration of alloxan monohydrate. ${ }^{18,19}$ After a period of three days, the rats with a blood glucose level greater than $250 \mathrm{mg} / \mathrm{dl}$ were considered diabetic and used for the next stage of the study.

\section{Experimental design for anti-diabetic study}

The alloxan induced diabetic rats were divided randomly into seventeen groups $(n=5)$. Groups 1 and 2 (the positive controls) were treated with 100 and $5 \mathrm{mg} / \mathrm{kg}$ body weight of metformin (MET) and glibenclamide (GLI) respectively. Groups 3, 4 and 5 received 100, 200, $400 \mathrm{mg} / \mathrm{kg}$ body weight of MDE. Groups 6 and 7 received co administered doses of $100 \mathrm{mg} / \mathrm{kg}$ MET $+100 \mathrm{mg} / \mathrm{kg}$ $\mathrm{MDE}$, and $5 \mathrm{mg} / \mathrm{kg} \mathrm{GL}+100 \mathrm{mg} / \mathrm{kg} \mathrm{MDE}$ respectively. Groups 8, 9 and 10 received 100,200 and $400 \mathrm{mg} / \mathrm{kg}$ of $\mathrm{HF}$ respectively. Groups 11, 12 and 13 received 100, 200 and $400 \mathrm{mg} / \mathrm{kg}$ body weight of EF. Groups 14, 15 and 16 received 100,200 and $400 \mathrm{mg} / \mathrm{kg}$ body weight of $\mathrm{MF}$. Group 17, the diabetic control received $0.4 \mathrm{ml}$ of $10 \%$ Tween 80 solution.

The standard agents, MDE and fractions were administered orally every 24 hours (daily) over a period of ten days. Blood glucose concentration and body weight were monitored at the end of days 2, 4, 6, 8 and 10 and PBGR calculated. Also at the end of 10 day treatment, animals in groups treated with the extract (MDE) and hexane fraction (HF), at $24 \mathrm{~h}$ after the last dose, were anaesthesized with ethyl ether vapour and blood samples were collected through retro-orbital plexus puncture and kept in plain tubes devoid of anticoagulant, centrifuged at $1000 \mathrm{rpm}$ for $15 \mathrm{mins}$ and then used for biochemical parameters' estimation.

The percentage blood glucose reduction rate was calculated for the various times and days using the formula: $\mathrm{PBGR}=\left(\mathrm{BGL}_{0}-\mathrm{BGL}_{\mathrm{T}} / \mathrm{BGL}_{0}\right) \times 100$.

Where $\mathrm{PBGR}=$ Percentage blood glucose reduction; $\mathrm{BGL}_{0}=$ blood glucose level at zero hour/days; $\mathrm{BGL}_{\mathrm{T}}=$ blood glucose level at a particular hour or day.

\section{Estimation of biochemical parameters on the extract and hexane fraction}

Serum lipid profiles which are high density lipoprotein (HDL), total cholesterol (TC), triglycerides (TG) were estimated using commercially available kits on the diabetic rats treated with MDE and HF in accordance with previously described method. ${ }^{20}$ The serum low density lipoprotein (LDL) and very low density lipoprotein (VLDL) were calculated using Friedewald formula: VLDL $=\mathrm{TG} / 5 ; \mathrm{LDL}=\mathrm{TC}-(\mathrm{HDL}+\mathrm{VLDL})$. Also percentage decrease in TC, TG, LDL-C and VLDL-C was determined.

\section{Statistical analysis}

Data obtained were analysed by SPSS (version 14) using the One Way Analysis of Variance (ANOVA) with Dunnett test for multiple comparisons with the control. Values are in mean \pm SEM and were considered significant at $\mathrm{P}<0.05$.

\section{RESULTS}

\section{Phytochemical analyses}

Qualitative analysis showed the presence of alkaloids, flavonoids, glycosides, tannins, steroids, proteins, saponins, reducing sugars and carbohydrates (Table 1). The degree of precipitation of the secondary metabolites however varied in the fractions with the hexane fraction having the highest average concentration of the constituents. The highest content of alkaloids $(4.67 \pm 0.2 \mathrm{mg} / 100 \mathrm{~g})$, glycosides $(1.08 \pm 0.1)$ and steroids $(6.22 \pm 0.30)$ were quantified in the hexane fraction. The ethyl acetate fraction however, had the highest quantity of flavonoids $(2.25 \pm 0.2)$, while the methanol fraction contained alkaloids $(2.14 \pm 0.1)$, steroids $(3.17 \pm 0.2)$ and soluble carbohydrates $(1.06 \pm 0.02)$ (Table 1$)$.

\section{Table 1: Quantitative and qualitative phytochemical analyses.}

\begin{tabular}{|lllll|}
\hline \multirow{2}{*}{ Constituent } & \multicolumn{4}{l}{ Concentration w/w $(\mathbf{m g} / 100 \mathrm{~g})$} \\
& MDE & MF & EF & HF \\
\hline Alkaloids & $4.87 \pm 0.2$ & $2.14 \pm 0.1$ & $3.86 \pm 0.1$ & $4.67 \pm 0.2$ \\
\hline Flavonoids & $3.34 \pm 0.2$ & $0.17 \pm 0.1$ & $2.25 \pm 0.2$ & $1.25 \pm 0.1$ \\
\hline Tannins & $1.13 \pm 0.1$ & - & $1.26 \pm 0.1$ & $1.24 \pm 0.1$ \\
\hline Glycosides & $0.58 \pm 0.1$ & $0.48 \pm 0.2$ & $0.65 \pm 0.1$ & $1.08 \pm 0.1$ \\
\hline Proteins & $1.72 \pm 0.2$ & $0.17 \pm 0.1$ & $0.55 \pm 0.3$ & $0.36 \pm 0.1$ \\
\hline Steroids & $5.24 \pm 0.2$ & $3.17 \pm 0.2$ & $4.21 \pm 0.1$ & $6.22 \pm 0.2$ \\
\hline Terpenoids & $0.35 \pm 0.1$ & - & $0.31 \pm 0.1$ & $0.27 \pm 0.3$ \\
\hline Carbohydrates & $1.68 \pm 0.1$ & $1.06 \pm 0.2$ & - & - \\
\hline & $-=$ not detectable. & & & \\
\hline
\end{tabular}

\section{Acute toxicity study (LD50)}

The results of acute toxicity studies showed no visible signs of toxicity on the animals, with an estimated $\mathrm{LD}_{50}$ 
greater than $5000 \mathrm{mg} / \mathrm{kg}$ since no mortality or lethality was recorded up to $5000 \mathrm{mg} / \mathrm{kg}$ dose of the extract.

\section{Normoglycemic test}

The extract (MDE) of Buchholzia coriacea seeds at all doses tested, did not exert any significant reduction in blood glucose level (BGL) of normoglycemic rats when compared to the control group (Table 2). Similar results were also recorded with the standard drug metformin. However, administration of glibenclamide $(5 \mathrm{mg} / \mathrm{kg})$ produced significant PBGR of $49.5 \%$ which was sustained throughout the experimental period (Table 2).

\section{Oral glucose tolerance test (OGTT)}

Results showed that within 30 minutes of starting the OGTT, blood glucose concentration almost doubled from its initial level as shown by the control (Table 3).
The hyperglycemia was however suppressed by the MDE, HF, EF and MF. The MDE at all doses $(100-400 \mathrm{mg} / \mathrm{kg})$ caused decrease in BGL from 30 minutes after glucose administration with highest percentage blood glucose reduction (PBGR) of $33.4 \%$ at $200 \mathrm{mg} / \mathrm{kg}$ compared to 6.0 and $30.81 \%$ of MET and GLI, respectively, after $2 \mathrm{~h}$ period.

Also HF, EF and MF (all at $100 \mathrm{mg} / \mathrm{kg}$ ) inhibited the postprandial increase in BGL after a heavy glucose meal with PBGR of 32.0, 24.0 and $7.78 \%$ for, respectively, after $2 \mathrm{~h}$ (Table 3).

However, only the HF exerted a sustained and progressive dose dependent inhibition of the postprandial rise in blood glucose level at all doses administered, when compared with the other fractions (Table 3).

Table 2: Effect of MDE on blood glucose concentration in normoglycemic rats.

\begin{tabular}{|c|c|c|c|c|c|}
\hline \multirow{2}{*}{ Treatment } & \multirow{2}{*}{ Dose (mg/kg) } & \multicolumn{4}{|c|}{ Blood glucose level (mg/dl) } \\
\hline & & $\mathbf{O} \mathbf{h}$ & $2 \mathrm{~h}$ & $4 \mathrm{~h}$ & $6 \mathrm{~h}$ \\
\hline Control & & $74.0 \pm 4.3$ & $81.3 \pm 1.85(-9.8)$ & $79.3 \pm 4.4(-7.1)$ & $88.3 \pm 7.4(-19.32)$ \\
\hline MET & 100 & $76.2 \pm 2.7$ & $65.5 \pm 7.3(14.0)$ & $66.2 \pm 6.4(12.8)$ & $60.7 \pm 5.2(20.3)$ \\
\hline GLI & 5 & $83.2 \pm 2.9$ & $43.7 \pm 4.3 *(49.5)$ & $46.7 \pm 3.3 *(43.8)$ & $49.2 \pm 2.2 *(40.8)$ \\
\hline MDE & 100 & $74.0 \pm 2.7$ & $79.0 \pm 5.5(6.7)$ & $71.6 \pm 4.1(3.2)$ & $74.3 \pm 6.9(0.4)$ \\
\hline & 200 & $78.7 \pm 5.2$ & $80.0 \pm 7.5(-2.5)$ & $66.7 \pm 5.6(14.4)$ & $70.0 \pm 5.2(11.0)$ \\
\hline & 400 & $100.2 \pm 3.3$ & $101.2 \pm 7.3(-1.2)$ & $96.2 \pm 1.3(3.9)$ & $90.0 \pm 3.6(10.1)$ \\
\hline MDE + MET & $100+100$ & $71.6 \pm 6.2$ & $68.6 \pm 0.6(4.3)$ & $64.3 \pm 2.6(11.3)$ & $66.3 \pm 4.1(7.19)$ \\
\hline MDE + GLI & $100+100$ & $67.6 \pm 4.7$ & $40.3 \pm 6.1 *(40.3)$ & $41.6 \pm 4.4 *(38.4)$ & $38.3 \pm 2.0 *(43.3)$ \\
\hline
\end{tabular}

Values are expressed as Mean \pm SEM; Significance at $* \mathrm{P}<0.05$ using ANOVA, post hoc - Dunnet's test compared with the control, $\mathrm{n}=$ 5 , while the numbers in parenthesis are the percentage blood glucose reduction (PBGR).

Table 3: Effect of extract and fractions on postprandial blood glucose level of normoglycaemic rats.

\begin{tabular}{|c|c|c|c|c|c|c|}
\hline \multirow{2}{*}{ Treatment } & \multirow{2}{*}{ Dose (mg/kg) } & \multicolumn{5}{|c|}{ Percentage blood glucose reduction (\%) } \\
\hline & & $0 \mathrm{~min}$ & 30 min & $60 \mathrm{~min}$ & $90 \mathrm{~min}$ & $180 \mathrm{~min}$ \\
\hline Control & & 0.0 & -36.00 & -28.00 & -25.40 & -9.32 \\
\hline MET & 100 & 0.0 & -9.50 & -3.40 & -3.40 & 6.00 \\
\hline GLI & 5 & 0.0 & 22.20 & 12.90 & 21.05 & $30.81 *$ \\
\hline \multirow[t]{3}{*}{ MDE } & 100 & 0.0 & $33.40^{*}$ & $22.60 *$ & $27.90 *$ & $31.30 *$ \\
\hline & 200 & 0.0 & 19.20 & $23.60 *$ & $31.50 *$ & $34.00 *$ \\
\hline & 400 & 0.0 & 0.80 & 1.20 & 4.20 & 16.30 \\
\hline MDE + MET & $100+100$ & 0.0 & 5.92 & 2.38 & 8.90 & 14.87 \\
\hline MDE + GLI & $100+5$ & 0.0 & $21.20^{*}$ & 4.65 & $23.80 *$ & 17.73 \\
\hline \multirow[t]{3}{*}{$\mathrm{HF}$} & 100 & 0.0 & 17.30 & 24.40 & $32.00 *$ & $32.80 *$ \\
\hline & 200 & 0.0 & 12.80 & 17.10 & 19.20 & $28.40 *$ \\
\hline & 400 & 0.0 & 11.20 & 12.30 & 16.12 & 18.30 \\
\hline \multirow[t]{3}{*}{$\mathrm{EF}$} & 100 & 0.0 & 14.00 & 17.20 & 12.60 & $24.60 *$ \\
\hline & 200 & 0.0 & 2.80 & 14.30 & $34.29 *$ & 16.50 \\
\hline & 400 & 0.0 & 5.10 & 3.41 & -0.80 & 14.50 \\
\hline \multirow[t]{3}{*}{ MF } & 100 & 0.0 & -4.00 & -3.20 & 0.00 & 7.78 \\
\hline & 200 & 0.0 & 20.20 & $44.60 *$ & $41.60 *$ & $49.40 *$ \\
\hline & 400 & 0.0 & -1.60 & -0.8 & 6.40 & 29.00 \\
\hline
\end{tabular}

Values are expressed as percentage blood glucose reduction of extracts and fractions, Significance at $* \mathrm{P}<0.05$ using ANOVA, post hoc Dunnet's test compared with the control, $\mathrm{n}=5$. 


\section{Effect of MDE and fractions on blood glucose level of diabetic rats}

The MDE at all doses administered exerted a significant $(\mathrm{P}$ $<0.05)$ reduction in blood glucose level $(\mathrm{BGL})$ on alloxan- induced diabetic rat and were sustained throughout the duration of the experiment. The highest percentage blood glucose reduction (PBGR) of $52.87 \%$ was shown by MDE $(200 \mathrm{mg} / \mathrm{kg})$ compared to PBGR of $42.79 \%$ and $34.18 \%$ of metformin and glibenclamide, respectively (Table 4).

Table 4: Percentage blood glucose reduction of extract and fractions on diabetic rats.

\begin{tabular}{|ll|llllll|}
\hline \multirow{2}{*}{ Treatment } & \multirow{2}{*}{ Dose $(\mathrm{mg} / \mathrm{kg})$} & \multicolumn{2}{l}{ Percentage blood glucose reduction $(\%)$} & \\
& & Day 0 & Day 2 & Day 4 & Day 6 & Day 8 & Day 10 \\
\hline Control & & 0.0 & -0.66 & -10.30 & -12.21 & -12.73 & -6.47 \\
\hline MET & 100 & 0.0 & -4.27 & -5.05 & 18.74 & 42.79 & 41.08 \\
\hline GLI & 5 & 0.0 & 1.46 & -3.89 & 19.83 & 34.18 & 2.71 \\
\hline MDE & 100 & 0.0 & 0.41 & 5.31 & 28.47 & 38.58 & 49.63 \\
\hline & 200 & 0.0 & -11.69 & -2.93 & 38.35 & $52.87^{*}$ & 34.82 \\
\hline & 400 & 0.0 & -11.92 & -0.41 & 13.74 & 18.54 & 22.30 \\
\hline MDE + MET & $100+100$ & 0.0 & 21.20 & 28.01 & $57.63^{*}$ & 47.78 & 38.59 \\
\hline MDE + GLI & $100+100$ & 0.0 & 1.72 & 13.4 & 18.32 & 32.45 & 17.65 \\
\hline HF & 100 & 0.0 & 18.66 & $38.66^{*}$ & $41.67^{*}$ & $42.11^{*}$ & $44.33^{*}$ \\
\hline & 200 & 0.0 & 6.66 & 15.37 & $28.35^{*}$ & $35.94^{*}$ & $47.54^{*}$ \\
\hline & 400 & 0.0 & 27.56 & 22.88 & $26.18^{*}$ & 34.30 & $38.84^{*}$ \\
\hline EF & 100 & 0.0 & 20.09 & 31.83 & 20.09 & 30.13 & 30.47 \\
\hline & 200 & 0.0 & -1.23 & 14.83 & $42.87^{*}$ & $42.32^{*}$ & 4.65 \\
\hline MF & 400 & 0.0 & -1.04 & $41.01^{*}$ & $47.01^{*}$ & 22.19 & $50.84^{*}$ \\
\hline & 100 & 0.0 & -38.56 & -0.84 & -33.19 & 1.62 & 1.41 \\
\hline & 200 & 0.0 & -12.08 & 29.16 & $40.73^{*}$ & 25.99 & 6.89 \\
\hline
\end{tabular}

Values represent PBGR of the extracts and fractions. Significance at $* \mathrm{P}<0.05$ using ANOVA, post hoc - Dunnet's test compared with the control, $\mathrm{n}=5$.

Table 5: Effects of extract and hexane fraction on the lipid profile of diabetic rats.

\begin{tabular}{|c|c|c|c|c|c|c|}
\hline \multirow{2}{*}{ Treatment } & \multirow{2}{*}{$\begin{array}{l}\text { Dose } \\
(\mathrm{mg} / \mathrm{kg})\end{array}$} & \multicolumn{5}{|c|}{ Concentration (mg/dl) } \\
\hline & & TC & TG & HDL-C & LDL -C & VLDL - C \\
\hline Diabetic control & - & $230.0 \pm 0.6$ & $161.6 \pm 0.5$ & $54.5 \pm 2.0$ & $128.2 \pm 0.8$ & $32.2 \pm 7.9$ \\
\hline MET & 100 & $\begin{array}{l}169.8 \pm 9.1 * \\
(26.2)\end{array}$ & $\begin{array}{l}92.9 \pm 13.1 * \\
(42.5)\end{array}$ & $\begin{array}{l}55 . .9 \pm 3.6 \\
(-2.6)\end{array}$ & $\begin{array}{l}75.2 \pm 5.5 * \\
(41.3)\end{array}$ & $\begin{array}{l}18.5 \pm 2.3 * \\
(42.5)\end{array}$ \\
\hline GLI & 5 & $\begin{array}{l}168.0 \pm 17.1^{*} \\
(27.0)\end{array}$ & $\begin{array}{l}92.9 \pm 5.7 * \\
(42.5)\end{array}$ & $\begin{array}{l}59.9 \pm 3.9 \\
(-9.9)\end{array}$ & $\begin{array}{l}82.5 \pm 5.7 * \\
(35.6)\end{array}$ & $\begin{array}{l}18.5 \pm 3.0 * \\
(42.5)\end{array}$ \\
\hline \multirow[t]{3}{*}{ MDE } & 100 & $\begin{array}{l}159.2 \pm 4.2^{*} \\
(30.8)\end{array}$ & $\begin{array}{l}118.8 \pm 7.8 \\
(26.5)\end{array}$ & $\begin{array}{l}52.8 \pm 1.9 \\
(3.1)\end{array}$ & $\begin{array}{l}57.2 \pm 2.4 * \\
(55.4)\end{array}$ & $\begin{array}{l}23.7 \pm 2.9 \\
(26.4)\end{array}$ \\
\hline & 200 & $\begin{array}{l}145.7 \pm 6.6^{*} \\
(36.7)\end{array}$ & $\begin{array}{l}134.3 \pm 12.5 \\
(16.9)\end{array}$ & $\begin{array}{l}47.8 \pm 0.8 \\
(12.3)\end{array}$ & $\begin{array}{l}39.3 \pm 4.0 * \\
(69.3)\end{array}$ & $\begin{array}{l}26.8 \pm 4.2 \\
(16.8)\end{array}$ \\
\hline & 400 & $\begin{array}{l}163.4 \pm 7.2 * \\
(29.0)\end{array}$ & $\begin{array}{l}103.3 \pm 9.2 * \\
(36.1)\end{array}$ & $\begin{array}{l}53.1 \pm 3.6 \\
(2.6)\end{array}$ & $\begin{array}{l}64.8 \pm 6.8 * \\
(49.5)\end{array}$ & $\begin{array}{l}20.6 \pm 3.2 \\
(36.0)\end{array}$ \\
\hline MDE + MET & $100+100$ & $\begin{array}{l}172.7 \pm 7.2 * \\
(24.9)\end{array}$ & $\begin{array}{l}115.0 \pm 3.6^{*} \\
(28.8)\end{array}$ & $\begin{array}{l}81.9 \pm 27.9 * \\
(-50.3)\end{array}$ & $\begin{array}{l}85.9 \pm 6.5 * \\
(33.0)\end{array}$ & $\begin{array}{l}23.0 \pm 9.9 \\
(28.6)\end{array}$ \\
\hline $\mathrm{MDE}+\mathrm{GLI}$ & $100+100$ & $\begin{array}{l}163.7 \pm 2.8 * \\
(28.8)\end{array}$ & $\begin{array}{l}106.1 \pm 10.9 * \\
(34.3)\end{array}$ & $\begin{array}{l}54.8 \pm 1.8 \\
(-0.6)\end{array}$ & $\begin{array}{l}64.4 \pm 8.4 * \\
(49.8)\end{array}$ & $\begin{array}{l}21.2 \pm 1.9 \\
(34.2)\end{array}$ \\
\hline \multirow[t]{3}{*}{$\mathrm{HF}$} & 100 & $\begin{array}{l}166.1 \pm 3.6^{*} \\
(27.8)\end{array}$ & $\begin{array}{l}125.8 \pm 10.8 \\
(22.2)\end{array}$ & $\begin{array}{l}52.5 \pm 1.6 \\
(3.7)\end{array}$ & $\begin{array}{l}61.0 \pm 6.9 * \\
(52.4)\end{array}$ & $\begin{array}{l}25.1 \pm 9.8 \\
(22.0)\end{array}$ \\
\hline & 200 & $\begin{array}{l}159.0 \pm 5.3 * \\
(30.9)\end{array}$ & $\begin{array}{l}126.3 \pm 8.8 \\
(21.8)\end{array}$ & $\begin{array}{l}48.7 \pm 0.8 \\
(10.6)\end{array}$ & $\begin{array}{l}58.1 \pm 4.7 * \\
(54.7)\end{array}$ & $\begin{array}{l}25.2 \pm 5.3 \\
(21.7)\end{array}$ \\
\hline & 400 & $\begin{array}{l}144.1 \pm 5.6^{*} \\
(37.3)\end{array}$ & $\begin{array}{l}113.2 \pm 5.8^{*} \\
(30.0)\end{array}$ & $\begin{array}{l}54.3 \pm 2.7 \\
(0.4)\end{array}$ & $\begin{array}{l}44.3 \pm 4.3 * \\
(65.4)\end{array}$ & $\begin{array}{l}22.6 \pm 8.9 \\
(29.8)\end{array}$ \\
\hline
\end{tabular}

Values represent Mean \pm SEM, Significance at $* \mathrm{P}<0.05$ using ANOVA, post hoc - Dunnet's test compared with the diabetic control, $\mathrm{n}=$ 5. Values in parenthesis represent percentage reduction while negative values represent percentage increase on the HDL-C. 
Similarly, the fractions exhibited significant $(\mathrm{P}<0.05)$ reduction in the mean blood glucose level with $\mathrm{HF}$ showing more potent effect at $100 \mathrm{mg} / \mathrm{kg}$ with PBGR of $44.33 \%$ on day 10 (Table 4). However, the combined effect of extract and metformin showed a significant $(\mathrm{P}$ $<0.05)$ and better efficacious effect in control of the blood glucose compared with the combined effect of extract and glibenclamide (Table 4).

\section{Effect of MDE and hexane fraction on lipid profiles of alloxanized diabetic rats}

Chronic treatment (10 days) with the MDE and HF significantly $(\mathrm{P}<0.05)$ decreased the serum concentration of total cholesterol (TC), low density lipoprotein (LDL) and triglyceride (TG) of the diabetic rats. At the lowest dose $(100 \mathrm{mg} / \mathrm{kg})$ the MDE and HF caused a percentage decrease in serum LDL of $55.4 \%$ and $52.4 \%$, respectively, exhibiting near same level of potency, while the standard agents MET and GLI showed $41.3 \%$ and 35.6\%, respectively (Table 5). However, HF showed significant ( $\mathrm{p}$ $<0.05$ ) dose-dependent percent decrease on all the lipid profiles tested except the HDL where it exhibited little increase. The combination treatment of MDE+MET and MDE+GLI caused an increase in serum HDL of $50.3 \%$ and $0.6 \%$, respectively (Table 5).

\section{Effect of extract and fractions on the body weight of diabetic rats}

The extract and fractions at doses tested showed an increase in body weight of the diabetic rats while the control (untreated) group manifested decrease in body weight (Table 6). The highest gain in body weight was observed among groups treated with the fractions.

Table 6: Effect of extract and fractions on the body weight of diabetic rats.

\begin{tabular}{|lllll|}
\hline Treatment & Dose $(\mathbf{m g} / \mathbf{k g})$ & Body weight $(\mathbf{g})$ & Average gain/loss in body weight $(\mathbf{g})$ \\
\hline Control & - & Day 0 & Day 10 & \\
\hline MET & 100 & $242.5 \pm 21.4$ & $219.0 \pm 8.10$ & -23.5 \\
\hline GLI & 5 & $261.5 \pm 22.7$ & $253.5 \pm 20.5$ & -8 \\
\hline MDE & 100 & $230.0 \pm 11.5$ & $246.2 \pm 11.6$ & 16.2 \\
\hline & 200 & $266.2 \pm 16.7$ & $274.5 \pm 25.0$ & 8.3 \\
\hline & 400 & $261.2 \pm 22.3$ & $276.5 \pm 22.2$ & 15.3 \\
\hline MDE+MET & $100+100$ & $255.0 \pm 3.5$ & $272.2 \pm 0.3$ & 17.2 \\
\hline MDE+GLI & $100+100$ & $247.0 \pm 17.1$ & $251.5 \pm 8.2$ & 4.5 \\
\hline HF & 100 & $258.7 \pm 16.3$ & $273.7 \pm 19.8$ & 15.0 \\
\hline & 200 & $236.5 \pm 8.5$ & $255.3 \pm 13.2$ & 18.8 \\
\hline & 400 & $187.5 \pm 21.0$ & $200.0 \pm 18.5$ & 12.5 \\
\hline EF & $205.2 \pm 2.7$ & $211.5 \pm 6.43$ & 6.3 \\
\hline & 200 & $270.0 \pm 19.8$ & $285.60 \pm 21.1$ & 15.6 \\
\hline & 400 & $220.5 \pm 11.8$ & $227.3 \pm 14.8$ & 6.8 \\
\hline MF & 100 & $230.0 \pm 19.8$ & $245.6 \pm 21.3$ & 15.6 \\
\hline & 200 & $261.5 \pm 13.1$ & $283.5 \pm 25.9$ & 22 \\
\hline & 400 & $265.0 \pm 8.4$ & $284.5 \pm 10.5$ & 19.5 \\
\hline
\end{tabular}

Values represent Mean \pm SEM, Significance at $* \mathrm{P}<0.05$ using ANOVA, post hoc-Dunnet's test compared with the diabetic control, $\mathrm{n}=$ 5 .

\section{DISCUSSION}

Recent epidemiological studies have shown that the prevalence of diabetes mellitus (DM) globally is quite on the increase, with its attendance complications that are adversely affecting the quality of life of patients. ${ }^{1}$ It is of note that the impact of this global rise if not appropriately checked will pose a serious global health burden. In this study, the antihyperglycemic and hypolipidemic effects of crude extract and fractions of Buchholzia coriacea seeds in alloxan-induced diabetic rats were evaluated. The extract (MDE) did not significantly reduce the fasting blood glucose level in non-diabetic normal rats, an indication of its antihyperglycemic effects. This correlated with the pharmacological actions of metformin which is antihyperglycemic unlike glibenclamide that is a hypoglycaemic agent which showed significant reduction of fasting blood glucose of non-diabetic rats. The import of this is that the extract in therapy may be devoid of hypoglycaemic side effects as often associated with agents such as glibenclamide and other sulphonylureas and very unlikely with biguanides such as metformin. ${ }^{21}$ This antihyperglycemic effect can also be buttressed by the fact that even in combination with metformin the extract exhibited 
non synergistic activity on blood level of non-diabetic normal rats. Additionally, the extract and fractions showed significant improvement in glucose tolerance which was exhibited in the oral glucose tolerance test (OGTT) in glucose-fed hyperglycemic normal rat and evoked a sustained reduction in the postprandial increase in the blood glucose. The mechanism of this effect could be ascribable to decrease in the rate of intestinal glucose absorption, stimulation of peripheral glucose utilization or enhancing glycolytic and glycogenic processes with concomitant decrease in glycogenolysis and gluconeogenesis. ${ }^{5}$ Interestingly, the control of postprandial blood glucose level (BGL) by agents helps to minimize both micro and macro-vascular complications associated with DM. ${ }^{22}$ Also chronic treatment with the extract and fractions of $B$. coriacea gave a significant decrease in blood glucose level (BGL) of diabetic rats compared to untreated diabetic rats. The percentage blood glucose reduction (PBGR) showed that hexane fraction $(\mathrm{HF})$ is the most potent and reduced the blood glucose by $44.33 \%$ $(100 \mathrm{mg} / \mathrm{kg})$ at the end of the treatment period among the tested fractions. In combined treatment with metformin (MDE+MET), the extract consistently and synergistically enhanced the blood glucose lowering effects of metformin. In vivo and in vitro studies have demonstrated that metformin stimulates the insulin-induced components of glucose uptake into skeletal muscle and adipocytes in both diabetic individuals and animal models. ${ }^{21}$ On the other hand, the extract in combination with glibenclamide (MDE+GLI) did not show any increase in PBGR. Suffice it to say that the seeds of Buchholzia coriacea have the potentials of synergistically enhancing the antihyperglycemic effects of metformin in diabetic rats which is an indication that both might be operating through same mechanisms of action in their blood glucose reduction activity by increasing the peripheral utilization of blood glucose. The extract in combination with glibenclamide did not show any synergistic action and therefore, one might rule out the stimulation of insulin release from pancreatic $\beta$-cells by the extracts and fractions of Buchholzia coriacea seeds. This is in tandem with our preliminary study on the seeds of Buchholzia coriacea, though without combination treatment with glibenclamide. ${ }^{13}$ Also, unlike glibenclamide, the extract did not significantly suppress BGL in overnight fasted normoglycemic animals. Moreover, other reports suggest that medicinal plants possessing antidiabetic effect mediate their activity by causing regeneration of beta-cells as well as providing protective effect on beta-cells from glucose toxicity, inhibition of hepatic glucose production and/or by correction of insulin resistance. ${ }^{23,24}$ Above all, the precise mechanism of action of the extract and fractions at this stage of the research work is yet to be determined. Furthermore, on lipid parameters, chronic oral administration of the extract (MDE) and hexane fraction, $\mathrm{HF}$, caused a significant reduction in total cholesterol (TC), triglycerides (TG), LDL and VLDL levels and also a concomitant significant increase in HDL (the good cholesterol) level of diabetic rats compared to the control. The effect of decreasing the levels of TC, TG, LDL and increasing that of HDL by dietary or drug therapy has been found very beneficial in preventing diabetic complications as well as improving lipid metabolism in diabetic patients. $^{25}$ Serum lipids are known to be elevated during diabetes and have been implicated in the development of artherosclerosis and other cardiovascular risk factors. ${ }^{26,27}$ Diabetes induced hyperlipidemia is attributable to excess mobilization of fat from the adipose tissues due to the under utilization of glucose. ${ }^{28}$ Therefore, the abnormal high concentration of serum lipids in diabetic untreated rats may be due to increase in the mobilization of the free fatty acids due to peripheral fat deposits as a result of defect in insulin secretion and/or action. Diabetic treatment and management often involves weight control. While standard agents such as thiazolidinediones may cause weight gain, others such as metformin may not making it a good candidate in obese diabetic patients due to its mechanism of action. The average gain in the body weights of diabetic rats treated with extract and fractions may offer therapeutic advantage in correcting muscle wasting associated with DM. The increase in body weight of the treated rats indicated reversal of the diabetic state often characterized by a severe loss in body weight as a result of loss or degradation of structural proteins. ${ }^{29}$ The quantitative phytochemical screening of the extract and fractions revealed the presence of plants' secondary metabolites that are likely to be responsible for the claimed activity. Among them are alkaloids, flavonoids, steroids, glycosides and tannins which appeared in appreciable quantities in the extract and hexane fraction (HF), as has been reported in similar studies. ${ }^{9}$ The HF has exhibited the most potent antihyperglycemic effects with the likelihood of containing the active phytoconstituent(s) which most likely will be a non polar constituent. Although, none of these phytoconstituents could be attributable to the claimed activity. Reports have shown that alkaloids and flavonoids have exhibited potent blood glucose lowering effects. ${ }^{30,31}$ Since these constituents are richly expressed in the MDE and HF, thus they may in part be responsible for the observed blood glucose lowering effect of the extract and fraction either alone or in synergy with one another. ${ }^{5}$ The seeds of $B$. corieacea gave an $\mathrm{LD}_{50}$ greater than 5000 $\mathrm{mg} / \mathrm{kg}$, an indication of high safety profile and more so since the seeds have been consumed locally as a delicacy and for treatment of various ailments for decades without obvious reports of toxicity.

\section{CONCLUSION}

The extracts and fractions of Buccholzia coreacea seeds possess anti-hyperglycemic effects on both fasting and postprandial blood glucose levels in diabetic rats and also showed anti-hyperlipidemic effects in diabetic rats. The extract also exhibited synergistic effects with metformin, a standard agent.

\section{ACKNOWLEDGEMENTS}

Authors would like to express appreciation to Mr. A. Ozioko of International Center for Ethnomedicine and 
Drug Development (Inter CEDD), Nsukka, Nigeria, for his assistance in plant collection.

Funding: No funding sources

Conflict of interest: None declared

Ethical approval: The study was approved by the National Health Research Ethics Committee (NHREC) of Nigeria, (NHREC/05/01/2008B)

\section{REFERENCES}

1. Guariguata L, Whiting DR, Hambleton I, Beagley J, Linnenkamp U, Shaw JE. Global estimates of diabetes prevalence for 2013 and projections for 2035. Diabetes Research and Clinical Pratice 2014;103(2):137-49.

2. Sharma VK, Kumar S, Patel HJ, Hugar S. Hypoglycemic activity of Ficus glomerata in alloxan induced diabetic rats. International Journal of Pharmaceutical Sciences Review and Research. 2010;1(2):18-22.

3. IDF. International Diabetes Federation Diabetes Atlas, $6^{\text {th }}$ Edition, Brussels, Belgium; 2013. Available at: http://www.diabetesatlas.org.

4. Peer N, Kengne AP, Motala AA, Mbanya JC. Diabetes in the African region: an update. Diabetes Research and Clinical Pratice. 2014;103(2):197-205.

5. Patel DK, Kumar R, Laloo D, Hemalatha S. Evaluation of phytochemical and antioxidant activities of the different fractions of Hybanthus enneaspermus (Linn.) F. Muall. (Violacea). Asian Pac J Trop Med. 2011;4(5):412-20.

6. Kavishankar GB, Lakshanidevi N, Marthy SM. Diabetes and medicinal plants-A review. Int J Pharm Biomed Sci. 2011;2(3):65-80.

7. Jung M, Park M, Lee HC, Kang YH, Kang ES, Kim SK. Antidiabetic agents from medicinal plants. Curr Med Chem. 2006;13(10):1203-18.

8. Grover JK, Yadav S, Vats V. Medicinal plants of India with anti-diabetic potential. J. Ethnopharmacol. 2012;81:81-100.

9. Ajayeoba EO, Onocha Pa, Nwozo SO, Sama W. Antimicrobial and cytotoxicity evaluation of Buchholzia coriacea stem bark. Fitoterapia. 2003;74(7-8):706-9.

10. Nweze NE, Asuzu IU. Antihelminthic effect of Buchholzia coriacea seeds. Niger Vet J. 2006;27(2):60-5.

11. Ezekiel OO, Onyeoziri NF. Preliminary studies on the antimicrobial properties of Buchholzia coriacea. African Journal of Biotechnology. 2009;8(3):472-4.

12. Mbata TI, Duru CM, Onwumelu HA. Antibacterial activity of crude seed extracts of Buchholzia coriacea E.on some pathogenic bacteria. Journal of Development Biology and Tissue Engineering. 2009;1(1):001-5.

13. Okoye TC, Akah PA, Ilogu CL, Ezike AC, Onyeto CA. Anti-diabetic effects of the methanol extract of Buchholzia coriacea and its synergistic effects with metformin. Asian Journal of Biomedical and Pharmaceutical Sciences. 2012;2(12):32-6.

14. Harborne JB. Phytochemical Methods: a guide to modern techniques of plant analysis. $2^{\text {nd }}$ Edition. London, Chapman and Hall; 1988:55-56.

15. Trease GE, Evans WC. Test book of Pharmacognosy, 11th ed. Brailliare Tindall and Macmillian Publishers, London; 1989:176-180.

16. Obadoni BO, Ochuko PO. Phytochemical studies and comparative efficacy of the extract and some haemostatic plants in Edo and Delta states of Nigeria. Glob J Pure Appl Sci. 2001;8:203-8.

17. Lorke D. A new approach to practical acute toxicity testing. Arch. Toxicol. 1983;54:272-89.

18. El-Demerdash FM, Yousef MI, Abou El-Naga NI. Biochemical study on hehypoglycemic effects of onion and garlic in alloxan-induced diabetic rats. Food and Chemical Toxicology. 2005;43:57-63.

19. Etuk EU. Animal models for studying diabetes mellitus. Agric. Biol. J. N. Am. 2010;1(2):130-4.

20. Muller PH, Schmulling RM, Eggstein M. A fully enzymatic triglyceride determination. J. Clin. Chem. 1977;15:457-504.

21. Bailey CJ. Biguanides and NIDDM. Diabetes Care. 1992;15:755-72.

22. Ceriello A. Postprandial hyperglycemia and diabetes complications; is it time to treat? Diabetes. 2005;54:17.

23. Grover JK, Vats V, Rathi S. Antihyperglycemic effects of Eugenia jambolana and Tinospora cordifolia in experimental diabetes and their effects on key metabolic enzymes involved in carbohydrate metabolism. J Ethnopharmacol. 2000;73(3):461-70.

24. Edduoks M, Jouad H, Maghrani M, Lemhadri A, Burcellin R. Inhibition of endogenous glucose production accounts for hypoglycaemic effect of Spergularia purpurea in streptozotocin mice. Phytomedicine. 2003;10:594-9.

25. Ahmed AM. Diabetic autonomic neuropathy. Saudi Med J. 2000;21(11):1034-7.

26. Mirinova MA, Klein RL, Virella GT, Lopes MF. Anti modified LDL antibodies, LDL-containing immune complexes and susceptibility of LDL to in vitro oxidation in patients with Type 2 diabetes. Diabetes. 2000;49:1033-49.

27. Okoli CO, Ibiam AF, Ezike AC, Akah PA, Okoye TC. Evaluation of antidiabetic potentials of Phyllantus niruri in alloxan diabetic rats. African Journal of Biotechnology. 2009;9(2):248-59.

28. Krishnakumar K, Auhusti KT, Viyammamal PL. Hypolipdemic effect of Solacia obloga wall root bark in streptozotocin diabetic rats. Med Sci. 2000;28:65b67.

29. Rajkumar L, Srinivasa N, Balasubramanian K, Govindarajulu P. Increased degradation of dermal collagen in diabetic rats. Indian $\mathbf{J}$ Exp Biol. 1991;29(11):1081-3.

30. Kobayashi K, Saito Y, Nakazuwa I, Yoshizaki F. Screening of crude drugs for influence on amylase 
activity and postprandial blood glucose in mouse plasma. Biol. Pharm. Bull. 2000;23:1250-3.

31. Fernandez SP, Wasowki C, Loscalzo LM, Granger RE, Johnston GA, Paladini AC, et al. Central nervous system depressant action of flavonoid glycosides. European J. Pharmacol. 2006;539(3):168-76.
Cite this article as: Akunne TC, Ilogu LC, Obi BC, Akah PA. Protective effects of Buchholzia coriacea seeds extract and fractions on blood glucose and hyperlipidemia in diabetic rats. Int $\mathrm{J}$ Basic Clin Pharmacol 2017;6:1856-64. 